\title{
Varroa destructor (Mesostigmata: Varroidae) in Costa Rica: population dynamics and its influence on the colony condition of Africanized honey bees (Hymenoptera: Apidae)
}

\author{
Rafael A. Calderón \& Johan W. van Veen \\ Centro de Investigaciones Apícolas Tropicales, Universidad Nacional, P.O. Box 475-3000, Heredia, Costa Rica. \\ Phone: (506) 2238-1868. Fax: (506) 2237-7043: rcalder@una.ac.cr
}

Received 17-VI-2007. Corrected 30-VI-2008. Accepted 31-VII-2008.

\begin{abstract}
The development of Varroa destructor Anderson \& Trueman (Mesostigmata: Varroidae) population dynamics in Africanized honey bees, Apis mellifera L. (Hymenoptera: Apidae) colonies was monitored from February to July 2004 in Atenas, Costa Rica. A correlation between the mite infestation level and the colony condition was evaluated. For each colony, infestation of varroa in adult bees was measured twice a month. Sticky boards were placed on the bottom boards of each colony to collect fallen mites. The condition of the colonies was evaluated by measuring the amount of brood and adult bees. Our results consistently showed that mite infestation on adult bees increased significantly in the experimental colonies, rising to $10.0 \%$ by the end of the experiment. In addition, the mean mite fall increased significantly over the course of the study in the treated $(\mathrm{R}=$ $0.72, \mathrm{P}<0.05)$ and untreated colonies $(\mathrm{R}=0.74, \mathrm{P}<0.05)$ to a level of 63.8 and 73.5 mites per day, respectively. The increase in varroa infestation coincided with a decrease in the amount of brood. Furthermore, adult bees with deformed wings or even without wings crawling in front of their hive occurred in highly infested colonies (mite infestation $=10.0 \%$ or more). Rev. Biol. Trop. 56 (4): 1741-1747. Epub 2008 December 12.
\end{abstract}

Key words: Varroa destructor, Africanized honey bees, population dynamics, mite infestation, colony condition.

Severe colony mortality has been reported in European honey bees (EHB) colonies in Europe and North America, due to Varroa destructor (Bailey and Ball 1991). Both adult bees and brood are parasitized. Nevertheless, reproduction occurs only inside capped brood cells (worker or drone brood) (Ifantidis 1983). Since $V$. destructor populations increase when brood is present, it would be expected that in tropical climates, where brood rearing takes place year-round, the effect of varroa would be even more devastating because reproduction never ceases. However, that has not been the case in tropical regions of South America, specifically in Brazil, where colony losses are not recorded (De Jong et al. 1984). As varroa dispersed through regions of Brazil, infestation rates of more than $10 \%$ were first reported in Africanized honey bee (AHB) colonies. However, a strong reduction of the infestation levels has been observed in several regions of Brazil, since the introduction of this parasite (Moretto et al. 1995). Nevertheless, regional differences in weather conditions and mite genotypes make it difficult to characterize the varroa population dynamics on AHB over a wide-spread area. Variation in mite fertility may be a consequence that the growth rates of varroa population vary between geographic locations (De Guzman et al. 2007).

In Costa Rica, we found greater percentages of fertile varroa mites than have been reported for AHB in Brazil (Calderon et al. 2003). In addition, as a consequence of varroa introduction, some beekeepers have reported the occurrence of newly emerged bees with 
damaged wings crawling in front of the hive and colony losses. So far, there are no reports on the mite population dynamics in the tropical region of Central America. The study of varroa population dynamics is necessary because the probability of a colony collapsing increases as the mite population grows (Calderone 1999).

We hypothesized that, due to the fact that brood rearing takes place year-round in AHB colonies in Costa Rica, varroa reproduction occurs through the year increasing the mite population in the colony. The aim of the present study was to investigate the population dynamics of $V$. destructor in AHB colonies under the tropical conditions of Costa Rica. In addition, the influence of $V$. destructor infestation in the colony condition is discussed.

\section{MATERIALS AND METHODS}

The study was carried out in Atenas, located in the Central Valley of Costa Rica province of Alajuela $\left(9^{0} 58^{\prime} \mathrm{N}, 84^{0} 24^{\prime} \mathrm{W}, 696 \mathrm{~m}\right.$ above sea level) from February to July 2004. The average daily temperature is $23.8^{\circ} \mathrm{C}$ and annual precipitation is $2132.1 \mathrm{~mm}$. This study was done in 29 Africanized colonies (single brood-chamber) of approximately equal strength. All colonies were requeened with mated sister queens reared from one Africanized mother, and the colonies were housed in Langstroth hives and fed alternatively with dry sugar and sugar syrup (1:1) during the nectar dearth in May to July.

Mite infestation levels: Twenty AHB colonies naturally infested by varroa were monitored to determine the variation in the mite infestation levels. Colonies were arranged in two groups of 10 hives each. Previous to the study, colonies of one group received two strips of Apistan ${ }^{\circledR}(10 \%$ fluvalinate) inserted into the brood nest for a treatment period of 42 days to minimize numbers of phoretic mites (start with a low mite infestation level). Apistan ${ }^{\circledR}$ was removed one month before the beginning of data collection (manufacturer's recommendations). Colonies of the other group did not receive treatment at all. For each colony, mite infestation in adult bees was measured twice a month and fallen mites were collected weekly from the bottom boards of the colony.

Test of adult bees: About 100 bees from the brood nest of each colony were brushed into glass jars using a cardboard funnel. Powder soap and water (5\% soap) was added to the bees and the mixture was shaken for one minute. The solution and bees were poured into a double sieve and then washed with a strong spray of water (running water) to wash all mites through the coarse sieve into the fine sieve. The coarse sieve was a $2-\mathrm{mm}$ wire screen and the fine was $0.05-\mathrm{mm}$ wire screen to guarantee proper separation of bees and mites. Mites and bees were counted to establish an infestation rate (number of mites/number of bees x 100).

Test of fallen mites: To assess the number of fallen mites, a $36 \times 45-\mathrm{cm}$ white card coated with a thin layer of petroleum jelly (vaseline) was placed on the bottom board of each colony. In order to avoid bees removing dead mites, the bottom board was modified using a metal lattice covering the entire bottom. The cards remained in the colonies for a period of six to eight days and were examined under a magnifying glass to determine the total number of fallen mites.

Mite infestation and colony condition: Mite infestation levels and colony condition (amount of brood and adult bees) were evaluated in a separate group of nine AHB colonies, for a six month period. These colonies did not receive treatment at all. The same methodology described above was used to evaluate varroa infestation in adult bees and fallen mites. The condition of the colonies was estimated by measuring the amount of brood and adult bees once a month. The amount of open and sealed brood was measured using a frame divided into squares of $5 \times 5 \mathrm{~cm}\left(25 \mathrm{~cm}^{2}\right)$. This frame was placed over each comb to measure and calculate the brood for the whole colony. Adult bee population was calculated by visual estimation of the number of combs occupied (covered) by adult bees. 
Statistical analysis: Statistical significance between varroa infestation and the study time was determined by T-Student test. A correlation test was used to determine the relationships among mite population growth and colony condition.

\section{RESULTS}

\section{Infestation levels of $V$. destructor in treated and untreated $\mathrm{AHB}$ colonies}

Adult bees: The levels of varroa infestation in adult bees increased significantly over time in treated (T-Student, $\mathrm{P}=0.003$ ) and untreated colonies (T-Student, $\mathrm{P}=0.0001$ ) (Fig. 1). The monthly increase in mite population was positively correlated through time in treated $(\mathrm{R}=0.76, \mathrm{n}=10, \mathrm{P}<0.05)$ and untreated colonies $(\mathrm{R}=0.77, \mathrm{n}=10, \mathrm{P}<0.05)$.

Natural mortality: The mean mite fall increased significantly over the course of the study in the treated $(\mathrm{R}=0.72, \mathrm{n}=10, \mathrm{P}<0.05)$ and untreated colonies $(\mathrm{R}=0.74, \mathrm{n}=10, \mathrm{P}<0.05)$ to a level of 63.8 and 73.5 mites per day, respectively (Figs. 2 and 3). The average total number of fallen mites was 2572 and 4388 per colony for treated and untreated colonies over the study period. A sudden decrease in fallen mites occurred during June in most of the colonies. This decrease in mite counts was probably related to ants removing varroa mites from the bottom boards.

\section{Varroa infestation level and colony condition}

Infestation in adult bees and number of fallen mites: Levels of varroa infestation in adult bees varied through time. Lowest infestations were recorded during the first three months of the experiments. By May, the levels of varroa infestation clearly increased, rising to $10.0 \%$ by the end of the experiment. There was a positive correlation between the monthly mite infestation in adult bees and the study time $(\mathrm{R}=$ $0.72, \mathrm{n}=12, \mathrm{P}<0.05$ ).

The mite fall increased steadily over the course of the study time to a level of 36.3 mites per day. Lowest mite counts were observed during the first two months of the experiment; whereas the highest were observed in May and July. The mean total number of fallen mites per colony was 2600 over the study period. The

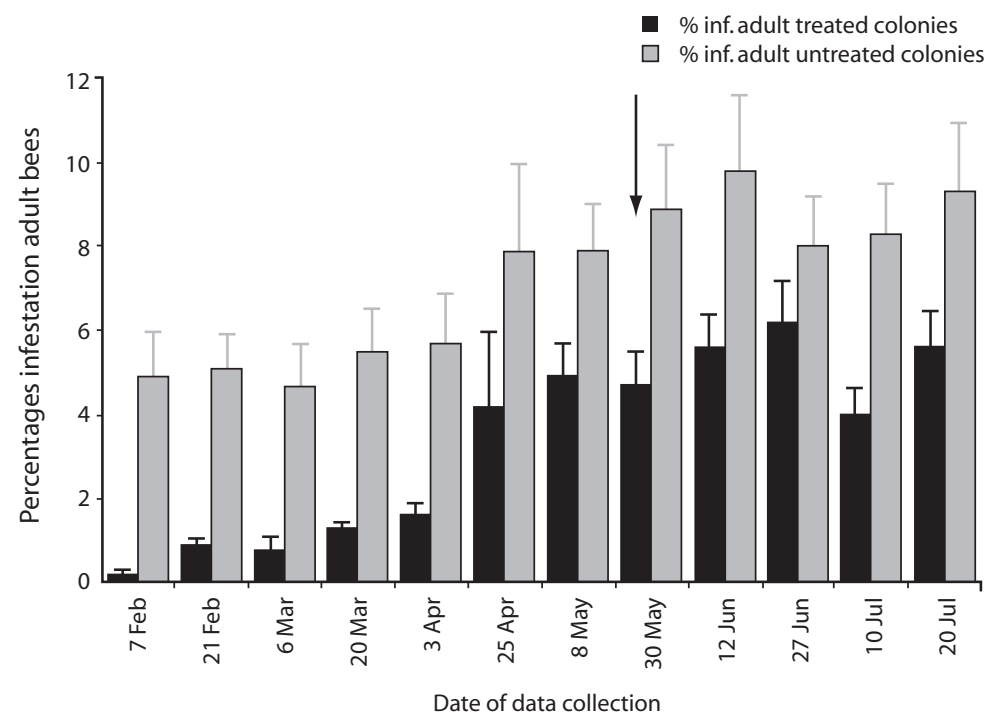

Fig. 1. The percentage of adult worker bees infested by $V$. destructor on treated and untreated AHB colonies through time (average values $\pm S E ; n=20$ colonies). The arrow indicates the beginning of the rainy season. 


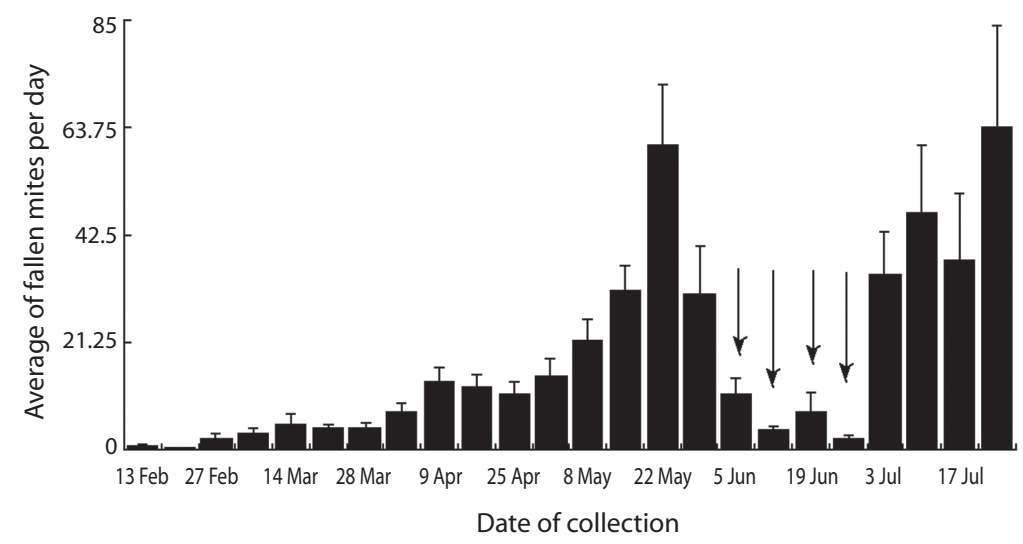

Fig. 2. The numbers of varroa mites collected from bottom boards in treated AHB colonies through study time. The results are presented as the daily average of fallen mites per colony (average values $\pm \mathrm{SE} ; \mathrm{n}=10$ colonies). The arrows indicate mite removal by ants from the sticky boards.



Date of collection

Fig. 3. The numbers of $V$. destructor collected from bottom boards in untreated AHB colonies through study time. The results are presented as the daily average of fallen mites per colony (average values $\pm \mathrm{SE} ; \mathrm{n}=10$ colonies). The arrows indicate mite removal by ants from the sticky boards. 
mite counts declined in most of the colonies through June due to the removal by ants. A positive correlation between the average daily fallen mites through time $(\mathrm{R}=0.48, \mathrm{n}=12$, $\mathrm{P}<0.05$ ) was observed.

Brood size and adult bee population (colony condition): The amount of brood was negatively correlated with varroa infestation, as measured in adult bees (sealed brood, $\mathrm{R}=$ $-0.99, \mathrm{n}=9, \mathrm{P}<0.05$; open brood $\mathrm{R}=-0.74, \mathrm{n}=9$, $\mathrm{P}<0.05$ ) and in fallen mites (sealed brood, $\mathrm{R}=$ $-0.35, \mathrm{n}=9, \mathrm{P}<0.05$; open brood $\mathrm{R}=-0.49, \mathrm{n}=9$, $\mathrm{P}<0.05$ ) (Fig. 4). The colonies had the highest amount of adult bees in April. During May and June the number of adult bees decreased, with its lowest numbers in July. Emerging bees with deformed and shortened wings or even without wings crawling in front of their hive were observed in five colonies. No brood mortality was evident in these colonies.

\section{DISCUSSION}

The varroa mite population determines its severely in honey bee colonies. It is known that mite populations vary according to bee genotype, mite genotype, geographical location, and climatic conditions (De Guzman et al. 2007).

A significant increase in varroa infestation level was observed in AHB colonies through the study. Infestation of up to $22.0 \%$ in adult bees, 191 fallen mites per day, and a total of 8000 mites found in some colonies during this study indicate that mite populations found in AHB colonies in Costa Rica are higher than those reported for AHB in Brazil. Varroa infestation in adult bees on AHB colonies in Brazil are mainly below 5\%; higher infestation levels were detected only during the first years of occurrence of varroa in this country (Rosenkranz 1999). The observed increases in varroa infestation in this study, despite the

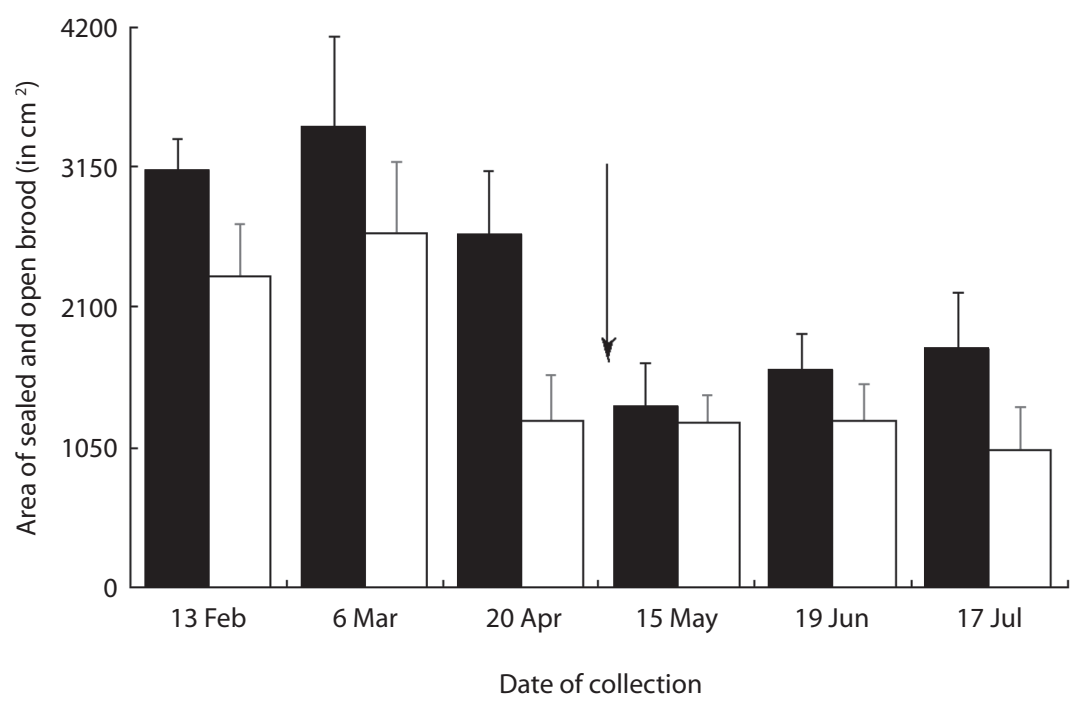

Fig. 4. The mean area of sealed and open brood (in $\mathrm{cm}^{2}$ ) recorded at monthly intervals in nine AHB colonies (average values $\pm \mathrm{SE} ; \mathrm{n}=9$ colonies). The arrow indicates the beginning of the rainy season (floral scarcity: May to July). 
low mite reproductive ability previously found in worker brood of AHB colonies, in which less than $30 \%$ of the foundress mites produced viable female offspring (Calderon et al. 2003), suggests that the number of mite reproductive cycles in worker brood (worker brood rearing takes place year-round) and varroa reproductive ability in drone brood, may be a significant factors related to the mite population growth in AHB colonies in Costa Rica.

When brood rearing peaked in March, the rates of varroa infestation in adult bees and the number of fallen mites were low. On the other hand, mite infestation increased in July, and this coincided with a decrease in the amount of brood in the colonies. De Guzman et al. (2007) reported a correlation between mite population growth and the number of capped brood present in Russian colonies in Baton Rouge, LA. According to Fries et al. (1994), before a colony becomes severely infested, the mite population begins to adversely affect the honey bee population, perhaps by interfering with brood production. In this situation, the colony appears restless and weak with reduced adult bee populations and decreased general conditions (De Jong 1997). In Yucatan, Mexico, Echazarreta and Paxton (1997) found a single annual peak of worker brood production in both AHB and EHB colonies between February and May. It should be considered that a decrease in brood production may lessen the availability of brood for infestation, and thereby provide a longer phoretic period for the mites and increase the number of foundress mites per cell (parasitic intensity).

The occurrence of adult bees with deformed wings or even without wings crawling in front of their hive, could be associated with a high mite infestation levels observed in some colonies later in the experiment. Shimanuki et al. (1994) have suggested the terminology "parasitic mite syndrome" for the symptoms of colonies that are infested with $V$. destructor. Among those symptoms are a reduced adult bee population, crawling bees in front of the hive, and queen supersedure (Hung et al. 1995). According to Ball (1996), much damage is due to secondary infections. It is known that deformed wing virus is transmitted by the mite (Ball 1985).

In conclusion, mite population in the experimental colonies increased through the study to significant levels. This increased in mite infestation coincided with a decrease in the amount of brood in the colonies. In addition, adult bees with deformed wings or even without wings crawling in front of their hive occurred in severely infested colonies. It will be useful to monitor the varroa population growth for long periods to find out if varroa population continues increasing, a damage threshold should be established.

\section{ACKNOWLEDGMENTS}

We thank the CINAT beekeepers Guillermo Ramirez and Sergio Gonzales for the assistance with the field work and beekeeper Olman Acuña for his cooperation and letting his AHB colonies at our disposal.

\section{RESUMEN}

La dinámica poblacional del ácaro Varroa destructor Anderson \& Trueman (Mesostigmata: Varroidae) en abejas africanizadas, Apis mellifera L. (Hymenoptera: Apidae) fue monitoreada de febrero a julio 2004, en Atenas, Costa Rica. Asimismo, se analizó la relación entre el nivel de infestación de varroa y la condición de la colmena. La infestación del ácaro $V$. destructor fue evaluada en abejas adultas dos veces al mes. Además, se colocaron trampas adhesivas en el fondo de la colmena para recoger los ácaros que caen naturalmente. La condición de la colmena fue determinada midiendo la cantidad de cría y la población de abejas adultas. La infestación del ácaro $V$. destructor en abejas adultas aumentó significativamente durante el estudio hasta alcanzar un $10.0 \%$. Igualmente, la caída natural de ácaros se incrementó, tanto en colmenas que fueron tratadas previamente con un acaricida químico $(\mathrm{R}=0.72, \mathrm{P}<0.05)$ como en colmenas sin tratamiento $(\mathrm{R}=0.74, \mathrm{P}<0.05)$, hasta llegar a 63.8 y 73.5 ácaros por día, respectivamente. El aumento de la infestación en las colmenas coincidió con una disminución en la cantidad de cría. La presencia de abejas adultas con alas deformes o sin alas, arrastrándose en frente de la colmena, fue observada en colmenas altamente infestadas con el ácaro de la varroa (infestación superior $=10.0 \%$ ).

Palabras clave: Varroa destructor, abejas africanizadas, dinámica poblacional, nivel de infestación, condición de la colmena. 


\section{REFERENCES}

Bailey, L. \& B.V. Ball. 1991. Honey Bee Pathology. Academic, London, United Kingdom.

Ball, B.V. 1985. Acute paralysis virus isolates from honeybee colonies infested with Varroa jacobsoni. J. Apic. Res. 24: 115-119.

Ball, B.V. 1996. Honey bee viruses: a cause for concern. Bee World 77: 117-119.

Calderón, R.A., M.J. Sommeijer, A. De Ruijter \& J.W. Van Veen. 2003 The reproductive ability of Varroa destructor in worker brood of Africanized and hybrid honey bees in Costa Rica. J. Apic. Res. 42: 65-67.

Calderone, N. 1999. Varroa mites: Integrated Pest Management. Bee Culture: 20-25.

De Guzman, L., T. Rinderer \& A. Frake. 2007. Growth of Varroa destructor populations in Russian Honey bee (Hymenoptera: Apidae) colonies. Ann. Entomol. Soc. Am. 100: 187-195.

De Jong, D., L. Goncalves \& R. Morse. 1984. Dependence of climate of the virulence of Varroa jacobsoni. Bee World 65: 117-121.

De Jong, D. 1997. Varroa and other parasites of brood, p. 280-327. In R. Morse and K. Flottum (eds).
Honey Bee Pest, Predators, and Diseases. A.I. Root Company, Ohio, USA.

Echazarreta, C. \& R. Paxton. 1997. Comparative colony development of Africanized and European honey bees (Apis mellifera) in lowland neotropical, Yucatan, Mexico. J. Apic. Res. 36: 89-103.

Fries, I., S. Camazine \& J. Sneyd. 1994. Population dynamics of Varroa jacobsoni: a model and a review. Bee World 75: 5-28.

Hung, A.C.F., J.R. Adams \& H. Shimanuki. 1995. Bee parasitic mite syndrome (II): the role of varroa mite and viruses. Am. Bee J. 135: 702-704.

Ifantidis, M.D. 1983. Ontogenesis of the mite Varroa jacobsoni in worker and drone honeybee brood cells. J. Apic. Res. 22: 200-206.

Moretto, G., A. Pillati, D. De Jong, L. Goncalves \& F. Cassini. 1995. Reduction of varroa infestations in the state of Santa Catarina, in Southern Brazil. Am. Bee J. 135: 498-500.

Rosenkranz, P. 1999. Honey bee (Apis mellifera L.) tolerance to Varroa jacobsoni Oud. in South America. Apidologie 30: 159-172.

Shimanuki, H., N.W. Calderone \& D.A. Knox. 1994. Parasitic Mite syndrome: the symptoms. Am. Bee J. 134: 827-828. 
